\title{
The Ottawa Field-Naturalists' Club Awards for 2007
}

\author{
Irwin M. Brodo, Christine Hanrahan, Diane LePage, and Eleanor ZurbrigG
}

On 26 April 2008, members and friends of the Ottawa Field-Naturalists' Club gathered at the Club's Annual Soirée at St. Basil's Church in Ottawa, and once again, awards were given to members, and one non-member, who distinguished themselves by accomplishments in the field of natural history and conservation, or by

\section{Member of the Year - Carla Hilado}

The Member of the Year award is given in recognition of a member who has contributed significantly to the Club in the previous year. Carla Hilado has worked at the Fletcher Wildlife Garden (FWG) for three years, and during that time has assumed more and more responsibilities, offering to help where needed, making practical suggestions, and initiating projects.

Carla joined the OFNC in 2001. In 2005 she joined the Backyard Garden (BYG) group, which meets each Friday morning throughout the gardening season at the Fletcher Wildlife Garden. She was interested in gardening and networking with other naturalists. As a recent graduate of the University of Guelph with a degree in Wildlife Biology, she felt that she could contribute to the FWG and, at the same time, learn from others. She soon discovered that this was indeed a great learning opportunity amidst wonderful company and so she decided that she would like to contribute more to other areas of the garden, as well as continuing to work in the BYG.

One of the FWG projects that caught her eye was the creation of a new addition to the Butterfly Meadow. A newly formed group began meeting on Wednesday evenings. In addition to planting wildflowers, she devoted a great deal of effort to controlling the invasive pale

\section{George McGee Service Award - Louis L'Arrivée}

The George McGee Service Award is given in recognition of a member who has contributed significantly to the smooth running of the Club over several years. For the past eight years, Louis L'Arrivée has been responsible for the mailing of the OFNC publication, Trail \& Landscape $(\mathrm{T} \& \mathrm{~L})$. Louis is a person who works "behind the scenes" and most members of the Club might not have heard of him or know about the amount of time he puts into organizing the mailing of Trail \& Landscape.

Four times a year he takes action. It begins with the notification of the proposed date when T\&L will be ready for mailing. Louis gets the ball rolling by contacting the membership committee chair for the current address list, and then he organizes the people who extraordinary activity within the Club. Careful observation of plants and animals, political savvy, selfless service, and teaching skills are all in evidence among this year's winners. The following citations for those who received an award were read to the members and guests assembled for the event.

swallowwort (dog-strangling vine.) Removal of this plant is not everyone's cup of tea, but Carla has been a constant and persistent hard-working presence, dedicated to making sure that the newly planted wildflowers are not over-run by the swallowwort. In 2007, she and other garden volunteers began work on mapping the Butterfly Meadow, and collecting and preparing seeds. Carla has also helped in removing invasive plants from the FWG Amphibian Pond.

Recently, Carla initiated organization of all the FWG brochures and information sheets. She created a spreadsheet that keeps track of the number of brochures and information sheets FWG has for distribution. Using this system makes it easier to establish how many of these items have been used and when the stock needs replenishing. This very organized system is a wonderful innovation for the FWG.

Carla's quiet presence and unassuming air sometimes leads one to overlook the work that she does. But she has contributed much to the garden, is a reliable and careful worker, and is absolutely dependable. She is also a real pleasure to work with. For all these reasons, we are proud to give Carla Hilado the OFNC's Member of the Year award.

assist him in the mailing. Prior to the mailing, he sorts and bundles the hundreds of mailing labels by postal code in order to ascertain the appropriate number of Canada Post containers and the correct machine readable postal codes. This ensures the publication is in the correct format to allow Canada Post to use its quick mailing process. He also makes sure there are enough peripheral supplies for the mailing to run smoothly and will often confirm with the editor and the printer concerning the correct T\&L mailing date.

Louis allows the use of his home for us to complete the necessary tasks for the mailing to take place. He is always well organized; everything is ready for us upon arrival. If someone is new to the group, he patiently explains the process and is willing to answer any 
question or offer any suggestions to help streamline the activity. The more unusual mailings, such as the international addresses requiring special attention, are always done by Louis personally. All this is conducted in a very warm, hospitable environment. His kindness and patience make it always a pleasure to assist in the mailing exercise.

When all the publications are ready for mailing, Louis prepares the Mailing Summary and brings the containers to the main post office (not all postal out- lets will accept pre-sorted mail containers), often on a Monday morning before he begins his work day.

Louis has been known to do all of this on very short notice, and at times re-arrange his weekday evenings to attend to the mailing when his weekends are filled with family activities. One notable mailing date was December 26, a testament to Louis' dedication.

For his outstanding service over many years, the OFNC is pleased to present the George McGee Service Award to Louis L'Arrivée.

\section{Conservation Award - Non-Member - Cliff Bennett}

This award is given in recognition of an outstanding contribution by a non-member (or group of nonmembers) in the cause of natural history conservation in the Ottawa Valley, with particular emphasis on activities within the Ottawa District.

Cliff Bennett is the recipient of this award for 2007, recognizing his contributions over many years to natural history conservation within the Ottawa Valley and in particular in the area of Almonte/Carleton Place. Cliff has demonstrated a sustained commitment to protection of the environment and has tirelessly worked over many decades to help people enjoy, understand and respect the natural world.

Cliff is a founding member of the Mississippi Valley Field Naturalists (in 1988), where he has held various offices including President and Director for many years, and sits on key club committees. He is in large part responsible for the growth and influence of the club over the years, and has worked ceaselessly to ensure that MVFN activities increase the environmental awareness of citizens. For example, Cliff established the MVFN's warmly received Environmental Education Projects Program (EEPP), which helps fund class field trips, visiting speakers and presentations on environmental topics in area schools. He also encouraged the MVFN to take on an ambitious Climate Change Awareness Project. Cliff helped develop a very popular guide to canoe outings and trail hikes complete with descriptions; these guides are posted on the MVFN website.
An avid birder, Cliff writes an excellent and very popular column, 'Speaking of Birds' for the Lanark Era newspaper, something he has done for many years. He coordinates the Carleton Place Christmas Bird Count, participates in the Baillie Birdathon to raise funds for bird research and conservation, and was instrumental in organizing participants of the MVFN for the Ontario Breeding Bird Atlas.

As a nature conservation advocate, Cliff has been influential on the Board of Directors of Ontario Nature, representing Eastern Ontario groups since 2005. He has been extremely busy and effective in this capacity, and local naturalist groups have already benefited from having such an articulate, informed and persuasive representative to the provincial conservation body. He also provided thoughtful environmental input into the new Community Official Plan for Mississippi Mills, helped to start up the Mississippi Madawaska Land Trust Conservancy to protect valuable natural areas in the region, participated on the Environmental Advisory Committee for the Lanark Highlands, effectively advocated for public trails in Lanark County, and was instrumental in establishing the North Lanark Trails Advisory Committee.

Cliff's active involvement in and commitment to natural history and conservation issues are long-standing, and shows no signs of waning. We are really fortunate to have such a dedicated and effective spokesperson for the conservation of our natural world.

\section{Conservation Award - Member - Erwin Dreessen}

The OFNC Conservation Award is given in recognition of a club member who has made an outstanding contribution toward protecting our natural environment in the Ottawa Region. Erwin Dreessen has been a prominent and vocal defender of urban greenspaces for many years. He has written articles, prepared reports, given presentations, and argued in a lucid and thought-provoking manner for the preservation and protection of natural areas in the nation's capital.

Erwin first became involved in land use issues in 1993, galvanized into action by development proposals for the Confederation Heights area. As a member of the Federation of Citizens' Associations, he served as Chair of their Land Use Committee.
From these beginnings, Erwin went on to help found the Greenspace Alliance (GA) in 1997, a very active and well-regarded citizen's group. He was Chair of the organization for several years as well as a director, and is now one of the moderators of the GA listserve. He continues to play a major role in the organization. One of his main functions has been to advance greenspace issues in the City of Ottawa Official Plan, advocating for retention and protection of wetlands, woodlots and other natural areas in the urban context. This is no small role. He monitors City development proposals, attends hearings and meetings with City staff, attends all OMB hearings in which greenspace issues are a factor, and prepares reports on same for the GA listserve. 
As a fellow Greenspace Alliance member noted, Erwin is a stickler for detail and accuracy, and his research is thorough. This ensures that the GA is always exceptionally well prepared when advocating the protection and preservation of Ottawa's greenspace, and such thoroughness has earned them much respect and attention.

A long-standing concern for Erwin has been the Southern Corridor, which includes McCarthy Woods. He has spent considerable time reviewing consultant's reports, Ottawa's Urban Natural Areas study, and liaising with other groups and individuals, arguing for the protection of the entire Southern Corridor, including the extensive meadow habitat. The meadow is significant both for wildlife and as a component of the Poets' Pathway project. The Poet's Pathway, a tribute to the nature-inspired Confederation Poets, envisages

\section{Anne Hanes Natural History Award - Ross Layberry}

The Anne Hanes Natural History Award recognizes excellence in natural history research by an amateur. This year the award goes to butterfly enthusiast and expert, Ross Layberry.

Ross shared the first Anne Hanes Natural History Award in 1982 with J. Donald Lafontaine and Peter Hall for writing the "Butterflies of the Ottawa District." (Trail \& Landscape volume 16, number 1). Sixteen years later this triumvirate wrote the seminal book Butterflies of Canada published by University of Toronto Press.

This year we are recognizing Ross for his recent article in Trail \& Landscape (volume 41, number 1), "Butterflies of the Ottawa District: 103 species... and counting." As this article testifies, Ross has continued over the years to be a keen field observer, meticulous collector of data, discriminating collector of specimens, and even a careful rearer of immatures. This has enabled him to fill in many gaps in our knowledge of the butterflies and, more importantly, to make that information available to all through his lucid writing. In the article, Ross explains why four species should no longer be included in the Ottawa butterfly fauna, and

\section{Mary Stuart Education Award - Martha Webber}

The Mary Stuart Education Award was established to recognize members, non-members or organizations, for their outstanding achievements in the field of natural history education in the Ottawa Region. The OFNC is pleased to give the award for 2007 to Martha Webber.

Martha Webber is much sought after by the Girl Guides, Boy Scouts, home schooling groups and others as a respected nature interpreter and resource person. Martha is an active member of the Council of Outdoor Educators of Ontario. Her study of native beliefs has encouraged her to know that people of all ages are com- a pathway spanning the greenspaces of urban Ottawa. Erwin was also very involved in helping prevent a golf course at Leamy Lake. As well, he has played a significant role in the Ottawa Land Trust projects. OFNC members may also remember Erwin's recent article in Trail \& Landscape (July-September 2007) on NCC holdings outside Gatineau Park and the Greenbelt. This quite exhaustive article is a must read for those who wish to understand more clearly the land acquisitions and disposals of the NCC.

Erwin Dreessen is a tireless champion of our urban natural areas, and his work is of the utmost importance to those who value greenspace preservation. For all his work on these issues, we are proud to present Erwin with the OFNC's Conservation Award - member for 2007.

why several others should be added. Most fascinating and impressive were the descriptions of his successful (and less successful) attempts at rearing the larvae of certain taxonomically problematic species such as the Summer Azure and Cherry Gall Azure in order to better understand the species' limits. This kind of careful, often frustrating work goes far beyond the ordinary "capture and list" activity of most butterfly collectors.

In addition to preparing well-written articles, Ross has made a very special contribution to our knowledge of local butterflies by his meticulous work in creating and maintaining a database of thousands of records of butterflies that is now available through the Canadian Biodiversity Information Facility under the auspices of Agriculture and Agri-Food Canada in Ottawa. This database is readily accessible to researchers and amateurs online.

Ross has been collecting butterflies since he was a child in England. He simply continued that interest as an amateur when he came here as a young man. He has become a leading expert in Canadian as well as local butterflies. We are pleased to present him with the Anne Hanes Natural History Award for 2007.

fortable in the out of doors when they acknowledge their kinship with nature.

Martha has a Masters degree in botany from the University of New Hampshire. While at the University of Wisconsin, she worked at various conservation camps as a counsellor, and attended the Ranger Naturalist Training School in Yosemite National Park. At the latter, she was involved with a myriad of wildlife studies, including banding bats and participating in an annual bird census. She taught high school biology for six years in Vermont, where she was involved with 
the development of the then new science of ecology. Eventually she and her family moved to rural Kanata, where she has lived for the last 30 years. It is here in her spacious gardens and adjacent natural areas that she runs many of her botany and natural history courses.

For a number of years Martha participated in the Ottawa Valley Field Trips, leading tours and giving courses on botanical subjects. Environmental programs for schools and other groups, nature day camps and back roads bus tours were some of the many activities Martha worked on.

Her summer nature interpretation day camps, Look and Listen Nature Camps, are limited to twelve children per group, and focus on personal awareness programs such as Project Wild and Tom Brown Junior's field exploration.
Martha also teaches courses in basic botanical identification as well as a six-week course in Edible Wild Plants that always ends with a wild food banquet. As well, she shares her knowledge of how native peoples used plants both for food and for medicine. In other courses, she instructs participants in the ecology of natural areas, discussing the interconnectedness of all things. Martha gives freely of her time to lead field trips for not-for-profit groups, taking people to some of the special wild places in our region. She continues to actively pursue protection for the Carp Ridge by conducting guided walks in the area, speaking to interested groups, writing letters, and meeting with politicians.

Martha has worked quietly and competently for many, many years, and it is time that she was recognized for this tremendous contribution to the study of natural history. 